\title{
Editorial: Progress in Reproductive Neuroendocrinology in Vertebrates
}

\author{
Kazuyoshi Tsutsui* and Takayoshi Ubuka* \\ Laboratory of Integrative Brain Sciences, Department of Biology, Center for Medical Life Science, Waseda University, Tokyo, \\ Japan
}

Keywords: gonadotropin-releasing hormone, gonadotropin-inhibitory hormone, kisspeptin, hypothalamus, pituitary, seasonal reproduction, social information, puberty

\section{Editorial on the Research Topic}

Progress in Reproductive Neuroendocrinology in Vertebrates

OPEN ACCESS

Edited and reviewed by: Cunming Duan, University of Michigan, United States

*Correspondence: Kazuyoshi Tsutsui k-tsutsui@waseda.jp Takayoshi Ubuka takayoshi.ubuka@gmail.com

Specialty section

This article was submitted to Experimental Endocrinology,

a section of the journal

Frontiers in Endocrinology

Received: 28 November 2019 Accepted: 06 December 2019 Published: 19 December 2019

Citation:

Tsutsui K and Ubuka T (2019) Editorial: Progress in Reproductive Neuroendocrinology in Vertebrates.

Front. Endocrinol. 10:895

doi: 10.3389/fendo.2019.00895
The hypothalamic-pituitary-gonadal (HPG) axis is imperative in the control of reproduction in vertebrates. It was thought that gonadotropin-releasing hormone $(\mathrm{GnRH})$ was the only hypothalamic neuropeptide that regulates the HPG axis since its discovery at the beginning of the 1970s $(1,2)$. However, two new key hypothalamic neuropeptides, i.e., gonadotropin-inhibitory hormone $(\mathrm{GnIH})$ and kisspeptin, have been found in the beginning of the 2000s to play key roles in the control of reproduction (3-6). In 2000, GnIH was discovered in the quail hypothalamus (3). Following intensive researches showed that GnIH inhibits gonadotropin synthesis and release through actions on GnRH neurons and gonadotropes via a G-protein coupled receptor (GPCR), GPR147, in birds and mammals (7). GnIH peptides were also identified in other vertebrate species from fish to humans. As in birds, mammalian and fish $\mathrm{GnIH}$ peptides inhibit gonadotropin release, indicating the conserved inhibitory role of $\mathrm{GnIH}$ in the regulation of the HPG axis (7). Following the discovery of $\mathrm{GnIH}$, kisspeptin, encoded by the Kiss1 gene, was discovered in mammals. In contrast to GnIH, kisspeptin has a stimulatory effect on GnRH neurons via another GPCR, GPR54 $(5,6)$. The Kiss1 gene was also identified in amphibians and fish (8). Therefore, we now know that $\mathrm{GnRH}$ is not the only hypothalamic neuropeptide controlling reproduction in vertebrates. The aim of this flagship Research Topic is to review the discoveries of GnIH and kisspeptin and the progress in reproductive neuroendocrinology made by these hypothalamic neuropeptides by collecting review articles from leading scientists in this new research field.

The first review article by Tsutsui and Ubuka summarizes the discovery of GnIH and progresses of GnIH research. GnIH was isolated and its structure was determined in 2000 (3). Its function that inhibits gonadotropin release was shown in quail in vitro (3) and in vivo (4). The article introduces that $\mathrm{GnIH}$ inhibits gonadotropin synthesis and release from gonadotropes by acting on gonadotropes and GnRH neurons via GPR147 $(9,10)$. The article also reviews that $\mathrm{GnIH}$ acts in the brain to regulate various behaviors (11-13). The second review article by Son et al. describes the molecular mechanisms of $\mathrm{GnIH}$ actions in target cells and how $\mathrm{GnIH}$ expression is regulated. Based on the morphology of $\mathrm{GnIH}$ neuronal fibers and $\mathrm{GnIH}$ receptor, GnRH neurons and gonadotropes are the major targets of $\mathrm{GnIH}$ action $(3,14-17)$. It was demonstrated that GnIH inhibits the adenylate cyclase (AC)/cAMP/protein kinase A (PKA)-dependent pathway both in $\mathrm{GnRH}$ neurons and gonadotropes $(9,10)$. The article further summarizes the mechanisms of how GnIH expression is regulated by glucocorticoid (18) and thyroid hormone (19). The third review article by Angelopoulou et al. introduces that RFRP-3, mammalian GnIH, is involved in the central control of daily and seasonal rhythms of reproduction to synchronize reproductive activity to environmental challenges. Melatonin and thyroid hormones may play critical roles in the regulation of $\mathrm{GnIH}$ neurons that convey environmental information to $\mathrm{GnRH}$ neurons and 
gonadotropes $(17,20-23)$. The fourth review article by Tobari and Tsutsui introduces the effects of social information on $\mathrm{GnIH}$ in birds (13). The article reviews researches that investigates the changes in the activities of $\mathrm{GnIH}$ neuronal system according to social status. The article introduces the pathway after visual perception of a potential mate and the rapid change in gonadotropin levels via the GnIH neuronal system in male birds. The fifth review article by Di Yorio et al. summarizes what are known and unknown about fish $\operatorname{GnIH}(24,25)$. The article emphasizes that teleost is characterized by three round whole genome duplication that could be responsible for the great phenotypic complexity and variability in reproductive strategies and sexual behavior. The fact may also affect the distribution of GnIH cell bodies and fibers and its relationship with GnRH variants. The article proposes that $\mathrm{GnIH}$ may have other functions than reproduction or act as an integrator in the reproductive process in teleosts. The last review article by Uenoyama et al. introduces the triggering role of kisspeptin that controls pubertal onset in mammals. Kisspeptin is a

\section{REFERENCES}

1. Burgus $\mathrm{R}$, Butcher $\mathrm{M}$, Amoss $\mathrm{M}$, Ling $\mathrm{N}$, Monahan $\mathrm{M}$, Rivier J, et al. Primary structure of the ovine hypothalamic luteinizing hormonereleasing factor (LRF) (LH-hypothalamus-LRF-gas chromatography-mass spectrometry-decapeptide-Edman degradation). Proc Natl Acad Sci USA. (1972) 69:278-82. doi: 10.1073/pnas.69.1.278

2. Matsuo H, Baba Y, Nair RM, Arimura A, Schally AV. Structure of the porcineLH- and FSH-releasing hormone. I The proposed amino acid sequence. Biochem Biophys Res Commun. (1971) 43:1334-9. doi: 10.1016/S0006-291X(71)80019-0

3. Tsutsui K, Saigoh E, Ukena K, Teranishi H, Fujisawa Y, Kikuchi M, et al. A novel avian hypothalamic peptide inhibiting gonadotropin release. Biochem Biophys Res Commun. (2000) 275:661-7. doi: 10.1006/bbrc.2000.3350

4. Ubuka T, Ukena K, Sharp PJ, Bentley GE, Tsutsui K. Gonadotropin-inhibitory hormone inhibits gonadal development and maintenance by decreasing gonadotropin synthesis and release in male quail. Endocrinology. (2006) 147:1187-94. doi: 10.1210/en.2005-1178

5. de Roux N, Genin E, Carel JC, Matsuda F, Chaussain JL, Milgrom E. Hypogonadotropic hypogonadism due to loss of function of the KiSS1derived peptide receptor GPR54. Proc Natl Acad Sci USA. (2003) 100:10972-6. doi: 10.1073/pnas.1834399100

6. Seminara SB, Messager S, Chatzidaki EE, Thresher RR, Acierno JS Jr, Shagoury JK, et al. The GPR54 gene as a regulator of puberty. N Engl J Med. (2003) 349:1614-27. doi: 10.1056/NEJMoa035322

7. Ubuka T, Son YL, Tsutsui K. Molecular, cellular, morphological, physiological and behavioral aspects of gonadotropin-inhibitory hormone. Gen Comp Endocrinol. (2016) 227:27-50. doi: 10.1016/j.ygcen.2015.09.009

8. Lee YR, Tsunekawa K, Moon MJ, Um HN, Hwang JI, Osugi T, et al. Molecular evolution of multiple forms of kisspeptins and GPR54 receptors in vertebrates. Endocrinology. (2009) 150:2837-46. doi: 10.1210/en.2008-1679

9. Son YL, Ubuka T, Millar RP, Kanasaki H, Tsutsui K. Gonadotropininhibitory hormone inhibits $\mathrm{GnRH}$-induced gonadotropin subunit gene transcriptions by inhibiting AC/cAMP/PKA-dependent ERK pathway in LBT2 cells. Endocrinology. (2012) 153:2332-43. doi: 10.1210/en.2011-1904

10. Son YL, Ubuka T, Soga T, Yamamoto K, Bentley GE, Tsutsui K. Inhibitory action of gonadotropin-inhibitory hormone on the signaling pathways induced by kisspeptin and vasoactive intestinal polypeptide in GnRH neuronal cell line, GT1-7. FASEB J. (2016) 30:2198-210. doi: 10.1096/fj.201500055

11. Ubuka T, Mukai M, Wolfe J, Beverly R, Clegg S, Wang A, et al. RNA interference of gonadotropin-inhibitory hormone gene induces arousal potent secretagogue of $\mathrm{GnRH}$ secretion therefore its release is fundamental to pubertal increase in GnRH/gonadotropin secretion. It is thought that puberty is timed by an increase in pulsatile $\mathrm{GnRH} /$ gonadotropin secretion in mammals. Recent researches suggest that kisspeptin/neurokinin $\mathrm{B} /$ dynorphin $\mathrm{A}$ (KNDy) neurons in the arcuate nucleus may play an important role in pulsatile $\mathrm{GnRH} /$ gonadotropin secretin during pubertal onset (26). The article further suggests that the timing of pubertal onset is controlled by upstream regulators of kisspeptin expression and release.

The review articles collected in this flagship Research Topic acknowledge that GnIH and kisspeptin play important roles in the hypothalamic control of reproduction, which is indispensable in developmental, seasonal, and social regulation of reproductive activities in vertebrates.

\section{AUTHOR CONTRIBUTIONS}

TU wrote the manuscript. KT edited the manuscript. in songbirds. PLoS ONE. (2012) 7:e30202. doi: 10.1371/journal.pone. 0030202

12. Ubuka T, Haraguchi S, Tobari $Y$, Narihiro $M$, Ishikawa $K$, Hayashi $\mathrm{T}$, et al. Hypothalamic inhibition of socio-sexual behaviour by increasing neuroestrogen synthesis. Nat Commun. (2014) 5:3061. doi: 10.1038/ncomms4061

13. Tobari Y, Son YL, Ubuka T, Hasegawa Y, Tsutsui K. A new pathway mediating social effects on the endocrine system: female presence acting via norepinephrine release stimulates gonadotropin-inhibitory hormone in the paraventricular nucleus and suppresses luteinizing hormone in quail. $J$ Neurosci. (2014) 34:9803-11. doi: 10.1523/JNEUROSCI.3706-13.2014

14. Ubuka T, Kim S, Huang YC, Reid J, Jiang J, Osugi T, et al. Gonadotropininhibitory hormone neurons interact directly with gonadotropin-releasing hormone-I and -II neurons in European starling brain. Endocrinology. (2008) 149:268-78. doi: 10.1210/en.2007-0983

15. Ubuka T, Lai H, Kitani M, Suzuuchi A, Pham V, Cadigan PA, et al. Gonadotropin-inhibitory hormone identification, cDNA cloning, and distribution in rhesus macaque brain. J Comp Neurol. (2009) 517:841-55. doi: 10.1002/cne.22191

16. Ubuka T, Morgan K, Pawson AJ, Osugi T, Chowdhury VS, Minakata H, et al. Identification of human GnIH homologs, RFRP-1 and RFRP-3, and the cognate receptor, GPR147 in the human hypothalamic pituitary axis. PLoS ONE. (2009) 4:e8400. doi: 10.1371/journal.pone.0008400

17. Ubuka $\mathrm{T}$, Inoue $\mathrm{K}$, Fukuda $\mathrm{Y}$, Mizuno $\mathrm{T}$, Ukena $\mathrm{K}$, Kriegsfeld LJ, et al. Identification, expression, and physiological functions of Siberian hamster gonadotropin-inhibitory hormone. Endocrinology. (2012) 153:37385. doi: 10.1210/en.2011-1110

18. Son YL, Ubuka T, Narihiro M, Fukuda Y, Hasunuma I, Yamamoto K, et al. Molecular basis for the activation of gonadotropin-inhibitory hormone gene transcription by corticosterone. Endocrinology. (2014) 155:1817-26. doi: 10.1210/en.2013-2076

19. Kiyohara M, Son YL, Tsutsui K. Involvement of gonadotropin-inhibitory hormone in pubertal disorders induced by thyroid status. Sci Rep. (2017) 7:1042. doi: 10.1038/s41598-017-01183-8

20. Ubuka T, Bentley GE, Ukena K, Wingfield JC, Tsutsui K. Melatonin induces the expression of gonadotropin-inhibitory hormone in the avian brain. Proc Natl Acad Sci USA. (2005) 102:3052-7. doi: 10.1073/pnas.0403 840102

21. Klosen P, Bienvenu C, Demarteau O, Dardente H, Guerrero H, Pévet P, et al. The mtl melatonin receptor and RORbeta receptor are co-localized in specific TSH-immunoreactive cells in the pars tuberalis of the rat pituitary. $J$ Histochem Cytochem. (2002) 50:1647-57. doi: 10.1177/002215540205001209 
22. Dardente H, Wyse CA, Birnie MJ, Dupré SM, Loudon ASI, Lincoln GA, et al. A molecular switch for photoperiod responsiveness in mammals. Curr Biol. (2010) 20:2193-8. doi: 10.1016/j.cub.2010.10.048

23. Klosen P, Sébert M-E, Rasri K, Laran-Chich M-P, Simonneaux V. TSH restores a summer phenotype in photoinhibited mammals via the RFamides RFRP3 and kisspeptin. FASEB J. (2013) 27:2677-86. doi: 10.1096/fj. 13-229559

24. Ubuka T, Parhar I. Dual actions of mammalian and piscine gonadotropininhibitory hormones, RFamide-related peptides and LPXRFamide peptides, in the hypothalamic-pituitary-gonadal axis. Front Endocrinol. (2018). 8:377. doi: 10.3389/fendo.2017.00377

25. Muñoz-Cueto JA, Paullada-Salmerón JA, Aliaga-Guerrero M, Cowan ME, Parhar IS, Ubuka T. A journey through the gonadotropin-inhibitory hormone system of fish. Front Endocrinol. (2017) 8:285. doi: 10.3389/fendo.2017. 00285
26. Ikegami K, Minabe S, Ieda N, Goto T, Sugimoto A, Nakamura S, et al. Evidence of involvement of neurone-glia/neurone-neurone communications via gap junctions in synchronised activity of KNDy neurones. J Neuroendocrinol. (2017) 29:1-14. doi: 10.1111/jne.12480

Conflict of Interest: The authors declare that the research was conducted in the absence of any commercial or financial relationships that could be construed as a potential conflict of interest.

Copyright (c) 2019 Tsutsui and Ubuka. This is an open-access article distributed under the terms of the Creative Commons Attribution License (CC BY). The use, distribution or reproduction in other forums is permitted, provided the original author(s) and the copyright owner(s) are credited and that the original publication in this journal is cited, in accordance with accepted academic practice. No use, distribution or reproduction is permitted which does not comply with these terms. 